\title{
ARISTOTLE'S DENIAL OF DELIBERATION ABOUT ENDS
}

\author{
Daniela Cammack ${ }^{1,2}$
}

\begin{abstract}
Although Aristotle stated that we do not deliberate about ends, it is widely agreed that he did not mean it. Eager to save him from implying that ends are irrational, scholars have argued that he did recognize deliberation about the specification of ends. This claim misunderstands Aristotle's conceptions of both deliberation and ends. Deliberation is not the whole of reasoning: it is a subcategory concerning only practical matters within our power. Not deliberating about something thus does not preclude other forms of reflection on it, such as that involved in specification. Yet on Aristotle's view, our ends are not in our power. They are generated not by individual choice but by nature, which in the case of human beings includes roles for both language and politics. Ends are thus beyond individual deliberation, though not beyond reason. This is no minor point. The claim that human beings can act rationally depends upon it.
\end{abstract}

For the last couple of generations, it has been widely agreed that, in an important passage, Aristotle did not mean what he appears to have said. What he appears to have said is that we do not deliberate about ends but only about means. What he is said to have meant is almost exactly the opposite. The most often quoted statement of his position is as follows:

We deliberate (bouleuometha) not about ends (peri tōn telōn), but about means (peri tōn pros ta telē). For a doctor does not deliberate (bouleuetai) whether he shall heal, nor an orator whether he shall convince, nor a statesman whether he shall produce law and order, nor does anyone else deliberate about his end (tou telous). ${ }^{3}$

On the face of it, it might seem difficult to imagine a less ambiguous denial that we deliberate about ends, but many scholars have insisted that Aristotle did not deny this. The correct interpretation of his claim, they argue, hinges on the translation of the phrase 'ta pros ta telè'. Though often rendered 'means', a more literal translation would be "things "toward", "conducing" or "pertaining" to ends'; and among things that pertain to ends, it is said, is one's specification of the end, that is, one's decision about 'what is to count as the end', and this Aristotle is said to have believed we deliberate about. ${ }^{4}$

${ }^{1}$ Junior Fellow, Harvard Society of Fellows, 78 Mount Auburn Street, Cambridge MA 02138, USA. Email: cammack@,fas.harvard.edu

2 I thank Dominic Burbidge, Paul Cammack, Jill Frank, Eugene Garver, David Grewal, Daniel Kapust, Melissa Lane and George Scialabba for comments on this article. I also thank Eugene Garver for inviting me to contribute to this volume. Translations are my own except where stated.

${ }^{3}$ NE 1112b12-20, trans. D. Ross, rev. J.O. Urmson and J.A. Ackrill (Oxford, 1998).

${ }^{4}$ D.J. Allan, 'Aristotle's Account of the Origins of Moral Principles', in Articles on Aristotle, ed. J. Barnes, M. Schofield and R. Sorabji (Bristol, 1977), pp. 72-8, p. 76; 
Indeed, nothing less than his conception of eudaimonia, 'happiness' or 'flourishing', is said to require this position. According to Aristotle, eudaimonia is constituted by numerous distinct goods, such as health, wealth, friendship, honour and virtue. ${ }^{5}$ Insofar as these goods are means to eudaimonia, they may presumably be deliberated about, yet insofar as they compose it, that deliberation concerns our ultimate end. ${ }^{6}$ Aristotle thus seems to contradict himself. But a solution is at hand: all we need assume, we are told, is that when Aristotle said 'we deliberate not about ends', he meant for the purpose of that particular deliberation. Of course while one is considering how to achieve a

S. Bickford, 'Beyond Friendship: Aristotle on Conflict, Deliberation and Attention', Journal of Politics, 58 (1996), pp. 398-421, pp. 400-3; J. Cooper, Reason and Human Good in Aristotle (Cambridge MA, 1975), pp. 19-22; T. Irwin, 'Aristotle on Reason, Desire and Virtue', Journal of Philosophy, 72 (1975), pp. 567-78; A. Mele, 'Choice and Virtue in the Nicomachean Ethics', Journal of the History of Philosophy, 19 (1981), pp. 405-23, pp. 421-2; R. Mulgan, 'Aristotle, Ethical Diversity and Political Argument', Journal of Political Philosophy, 7 (1999), pp. 191-207, p. 197-8; M.C. Nussbaum, Aristotle's De Motu Animalium (Cambridge MA, 1985 [1978]), pp. 170-1; M.C. Nussbaum, The Fragility of Goodness (Cambridge, 2001 [1986]), pp. 296-7; M.C. Nussbaum, Love's Knowledge (Oxford, 1998), pp. 60-2, 73; W. Olmsted, 'Ethical Deliberation in Aristotle's Rhetoric and Nicomachean Ethics', this volume; R. Ruderman, 'Aristotle and the Recovery of Political Judgment', American Political Science Review, 19 (1997), pp. 409-20, pp. 415-16; D. Wiggins, 'Deliberation and Practical Reason', Proceedings of the Aristotelian Society, 76 (1975-6), pp. 29-51. The quotation is from Nussbaum, Fragility, p. 297. Useful alternative accounts appear in E. Garver, Confronting Aristotle's Ethics (Chicago, 2006), esp. pp. 36-9; J. Moss, “Virtue Makes the Goal Right”: Virtue and Phronesis in Aristotle's Ethics', Phronesis, 56.3 (2011), pp. 204-61; H. Segric, From Portagoras to Aristotle (Princeton, 2009), pp. 89-171; and T. Tuozzo, 'Aristotelian Deliberation is Not of Ends', in Essays in Greek Philosophy IV: Aristotle's Ethics, ed. J.P. Anton and A. Preus (New York, 1991), pp. 193-213..

${ }^{5}$ The most comprehensive list appears at Rhet. 1360b: noble birth, numerous friends, good friends, wealth, good and numerous children, health, beauty, strength, stature, physical fitness, good reputation, honour, good luck and virtue. On this passage, see E. Garver, 'Deliberative Rhetoric and Ethical Deliberation', this volume. On the 'inclusive' versus the 'dominant' conceptions of eudaimonia, see W.F.R. Hardie, 'The Final Good in Aristotle's Ethics', in Aristotle, A Collection of Critical Essays, ed. J.M.E. Moravcsik (Garden City, 1967), pp. 297-322; J. Ackrill, 'Aristotle on Eudaimonia', Proceedings of the British Academy, 60 (1974), pp. 339-59; R. Majithia, 'On the Eudemian and Nicomachean Conceptions of Eudaimonia', American Catholic Philosophical Quarterly, 79 (2005), pp. 365-88.

${ }^{6}$ In Irwin's words: 'The practical intelligence is not concerned with means as opposed to ends. Insofar as it is concerned with constituent "means," it is also concerned with ends and, thereby, forms wishes for particular ends' (Irwin, 'Aristotle on Reason', p. 71). See also Bickford, 'Beyond Friendship', pp. 400-3; Cooper, Reason and Human Good, pp. 19-22; R. Majithia, 'Function, Intuition and Ends in Aristotle's Ethics', Ethical Theory and Moral Practice, 9 (2006), pp. 187-200, p. 191; Mele, 'Choice and Virtue', pp. 421-2; Mulgan, 'Ethical Diversity', p. 197; Nussbaum, Fragility, p. 297; Nussbaum, Love's Knowledge, pp. 61-2, 73; Wiggins, 'Deliberation and Practical Reason', pp. 32-8. 
given goal one does not simultaneously deliberate about the goal itself. But the goal will have been subject to prior deliberation. A doctor may not now deliberate about whether he shall heal, but he will have deliberated about whether to become a doctor, and hence indirectly about whether he would heal. To suggest otherwise would seem 'absurd'. ${ }^{7}$ Hence, it is said, Aristotle did not mean that we never deliberate about ends, only that we do not deliberate about ends and means at the same time. ${ }^{8}$

This reasoning has one major point in its favour. It seems to save Aristotle from implying that ends are irrational, the result of mere passion or desire. As Irwin puts it: 'If reason can move us only by identifying means to an end chosen by desire, it cannot influence our choice of ultimate end'; and if reason cannot influence our choice of ultimate end, it follows that all our ends are irrational, and human beings mere slaves to their passions. ${ }^{9}$ Had Aristotle believed this, it would not only put him in the otherwise incongruous company of Hume and most modern economists and social scientists, ${ }^{10}$ it would also show him to have completely contradicted his own account of the role of the intellect in human activity, including in the realization of eudaimonia. ${ }^{11}$ This, in turn, would embarrass the many admirers of Aristotle who have drawn on him to argue against the Humean view. ${ }^{12}$

These are powerful reasons to abide by the accepted interpretation. Yet certain cracks in it suggest it ought to be reconsidered. There is in fact good reason to think that Aristotle believed neither that we deliberate about ends nor that ends are irrational, and that this position was amply justified by his account of human agency and the structure of the human psyche. The case hinges not on the interpretation of the words ta pros ta tele, but rather on his conceptions of deliberation (to bouleuesthai) and ends, which are narrower than their modern English counterparts would suggest.

${ }^{7}$ Nussbaum, De Motu, p. 171; Wiggins, 'Deliberation and Practical Reason', p. 35.

${ }^{8}$ In Ackrill's words, 'any particular piece of deliberation must take some good, aim, or principles for granted' (J.L. Ackrill, Aristotle's Ethics (London, 1973), p. 27). See also Bickford, 'Beyond Friendship', pp. 401-2; Aurel Kolnai, 'Deliberation is of Ends', Proceedings of the Aristotelian Society, 62 (1961-2), pp. 195-218, p. 196; Majithia, 'Function, Intuition and Ends', p. 191; Mele, 'Choice and Virtue', p. 422; Nussbaum, De Motu, p. 171; Nussbaum, Fragility, p. 297; Olmsted, 'Ethical Deliberation', this volume; R. Sorabji, 'Aristotle on the Role of Intellect in Virtue', Proceedings of the Aristotelian Society, 74 (1973-4), pp. 107-29, p. 110; Wiggins, 'Deliberation and Practical Reason', pp. 33-6.

9 Irwin, ‘Aristotle on Reason', p. 567.

10 'Reason is, and ought only to be the slave of the passions, and can never pretend to any other office than to serve and obey them', D. Hume, Treatise on Human Nature, II.iii.3. See further Allan, 'Aristotle's Account', p. 74; Irwin, 'Aristotle on Reason', pp. 567-70; Wiggins, 'Deliberation and Practical Reason', p. 36, with note.

11 Sorabji, 'Role of Intellect'.

12 See e.g. J. Annas, 'Virtue Ethics', in Oxford Handbook of Ethical Theory, ed. D. Copp (Oxford, 2005), pp. 515-36, p. 518. Cf. Nussbaum, Love's Knowledge, pp. 56, 62. 
Happily, this means that less is at stake here than has been feared. Not deliberating about ends does not make them irrational, and since Aristotle regarded most ends as means from the point of view of the agent, the scope of deliberation remains wide. Yet his reasoning does pose a challenge, for it asks us to abandon the conviction that our ultimate ends are matters of personal choice. The notion that we choose our own ends is deeply ingrained in post-Christian and particularly post-Kantian moral thought; indeed on some accounts ends are all that we choose. ${ }^{13}$ To deny it is thus to deny a widely accepted notion of moral autonomy. Nonetheless Aristotle did deny it, and what is more, the claim that human beings can act rationally arguably demanded this denial.

I

\section{Cracks in the Current View}

There are several reasons to doubt the accepted interpretation of Aristotle's denial of deliberation about ends. To begin with, defining ta pros ta tele, 'things pertaining to ends', to include the question of 'what is to count as an end' inevitably blurs the distinction between the concepts ta pros ta tele and ta telē. If deliberation about what conduces to an end can be said to include deliberation about what is to count as the end, it is not clear what separate content remains to be captured by the phrase 'deliberation about the end'. Surely deliberation about 'what is to count as' the end itself counts as deliberation 'about' the end? Yet if so, instead of two distinct concepts, 'the end' and 'things conducing to the end', we would appear to be dealing with only one, 'things conducing to the end', which in turn encompasses the specification of the end. The original distinction between the two concepts is thus erased.

This should not come as a surprise. Erasing the distinction between 'ta pros ta tele' and 'ta tele' must necessarily be the prime goal of those who seek to claim that both can be the object of deliberation, in the teeth of Aristotle's declaration that this is true of only one. Nothing else would enable scholars to argue that we really do deliberate about ends. Nonetheless, the move has problematic consequences. First, it makes nonsense of the term 'ta pros ta telè , since that term itself presupposes the distinction between a telos and something pros it that the favoured interpretation of the passage dissolves. It also begs the question why, if both ends and things that conduce to them can be deliberated about, Aristotle should have bothered to distinguish between them in his account of deliberation in the first place. Moreover, he repeats the same claim several times, ${ }^{14}$ while extensions and elaborations are still more

${ }^{13}$ E.g. Kolnai, 'Deliberation is of Ends'.

${ }^{14}$ NE 1112b32, 1141b10-15 and 1142b32-1143a5; EE 1226b10-13, 1227a7-12, 1227b28; Rhet. 1362a15. 
numerous. ${ }^{15}$ The existence of a distinction between ends and things conducive to them is in fact a key presupposition of a great deal of Aristotle's ethical reasoning. ${ }^{16}$ It is not trivial to suggest that this distinction may be null.

These difficulties are not resolved by the suggestion that deliberation about ends takes place at an earlier time. Aristotle firmly resisted the idea that deliberation could run into infinity, and insisted that there had to be a 'stop'. ${ }^{17}$ Indeed, he argued that those who claimed otherwise abolished the very nature of the good and with it the entire possibility of intelligent action. ${ }^{18}$ Accordingly, it seems prima facie unlikely that he would have described eudaimonia and its constituents as things that could be deliberated about, and this is confirmed by an examination of the language he uses in connection with these concepts. Though it has been argued that Aristotle 'plainly recognises' deliberation about the content of ends - what, it is asked, are his own ethical inquiries if not a series of such deliberations? - Aristotle does not actually use the verb bouleuomai, 'deliberate', to describe this kind of reflective activity. ${ }^{19}$ Rather, when referring to his own philosophical investigations, he uses skeptomai, 'consider', ${ }^{20}$ theōreō, 'theorise' or 'contemplate', ${ }^{21}$ and skopeuō, 'examine'. ${ }^{22}$ On the issue of the specification of ends, favoured terms are $z \bar{e} t e \bar{o}$, 'search for' ${ }^{23}$ and horizo, 'define' or 'determine'. ${ }^{24}$ No such phrase as bouleuteon peri eudaimonias, 'let us deliberate about happiness', appears in his work, nor to my knowledge anywhere else in our ancient Greek texts.

A clue as to why this might be is found in Aristotle's account of animal movement. There, he uses noeo, 'think', and nous, 'thought', to describe the rational animal's relationship to the thing for the sake of which he moves. ${ }^{25}$ This is significant because nous is associated by Aristotle with the theoretical part of the intellect, in contradistinction from phronesis, the practical part,

${ }^{15} N E$ 1111b25-30, 1113a14-b5, 1140b15-25, 1144a5 and 1145a2-3; EE 1227b12-40; Rhet. 1362a15-b.

16 See e.g. EE 1217a35, 1218b10-25; MA 700b13; Met. 981a15-982b30, 994a-b, 1048b19-35; NE 1094a20, 1097a20-b10, 1176b28-1177b20; DA 407a25, 434a30; Pol. 1257b25-35, 1281a, 1323b20, 1324a10-1325a15, 1328a, 1331b25-1332a1, 1333a1-35, 1337b7-15, 1338a10-15, 1339b35; Rhet. 1360b5, 1363b-1364a, 1366a1-5.

17 Met. 994a7-10, 994b9-17; NE 1113a1-2, 1142a30; EE 1248a17-22.

18 Met. 994b9-17.

${ }_{19}$ Nussbaum, Fragility, p. 297. She cites Met. 1032b27, Pol. 1325b16 and 1338b2-4, and $N E 1144 \mathrm{a} 3 \mathrm{ff}$. in defence of this view. However, none of these passages feature the verb bouleuomai. Cf. Allan, 'Aristotle's Account', p. 73.

${ }^{20}$ EE 1214a15, 1217b1, 1218b27; Pol. 1324a14.

${ }^{21}$ HA 491a; Met. 1001a4; NE 1104a12, 1139a1; Pol. $1334 \mathrm{~b} 5$.

${ }^{22}$ EE 1214b29, 1217b16; NE 1112a10.

${ }^{23}$ EE 1218b7; NE 1097a15-30, 1112b20.

24 EE 1214b12, 1218b18; Pol. 1323a15 (diorisasthai).

${ }^{25} M A$ 701a130-135. 
which is the part he associates with deliberation. ${ }^{26}$ Nous is also the part of the intellect that Aristotle held to be responsible for the apprehension of ends. ${ }^{27}$ This suggests that he may not have supposed that not deliberating about ends would preclude other forms of rational activity in relation to them, including quite possibly their specification. It suggests that he regarded deliberation as a subcategory of reason rather than as equivalent to it - which is indeed exactly how he presents it. ${ }^{28}$

Aristotle's conception of deliberation may thus have been considerably narrower than recent readers have supposed. To some extent, modern English usage may have obscured this possibility, since 'deliberation', 'thought' and 'reasoning' are often used interchangeably. ${ }^{29}$ But Aristotle's terminology was both more variegated and more precise. His conceptions of deliberation and ends require similar treatment.

\section{II}

\section{Deliberation Reconsidered}

Let us temporarily put aside the issue of ends and focus on what Aristotle said we do deliberate about. In the Rhetoric, deliberation is associated with deciding policy in assemblies, judging cases in court, and being persuaded or otherwise by oratorical displays. ${ }^{30}$ The same text stipulates that the most important subjects for deliberation are public finance, war and peace, territorial defence, imports and exports and legislation. ${ }^{31}$ In the Politics, the term refers primarily to decision-making by assemblies and councils, ${ }^{32}$ while in Aristotle's ethical writings it is generally tied to the individual practice of arts, including medicine, military strategy and statesmanship, though legislative activity also appears in passing. ${ }^{33}$

Aristotle explained what these situations have in common in several different texts. The basic rule is that deliberation concerns tōn eph' hēmin kai praktōn, 'things from us and practical', or more elegantly, 'practical matters within our power'. ${ }^{34}$ Of special interest are matters where 'the exact results of

${ }^{26} N E$ 1140a25-35, 1141b10-15, 1142b32. See also DA 427a15-b10 and Rhet. $1362 \mathrm{a} 20$.

27 NE 1141a7, 1143a25 ff.; MA 701a28-35; DA 433a10-15. Cf. Rhet. 1362a20-25.

${ }^{28}$ NE 1139a5-16; Pol. 1333a25-26. Cf. DA 427a15-17, 429a22, 433a10-15. Cf. D. Depew, 'Why Aristotle Says Rhetorical Art Can Happen in Only a Few Venues', this volume.

29 As in e.g. Nussbaum, Fragility, pp. 313-17.

${ }^{30}$ Rhet. 1358b1-5, $1357 \mathrm{a} 5$.

31 Rhet. 1359b15-20.

32 Pol. 1275b15-20, 1298b12-1299a2.

33 NE 1112b5-6, 13-14; EE 1226a28-33, 1227a18-19. See also Met. 1013a17-25.

${ }^{34}$ NE 1112a30-31. Cf. EE 1226a26-33; Rhet. 1357a6-7. 
our actions are unclear', or where things are 'indeterminate' ${ }^{35}$ As Aristotle observes in the Rhetoric, 'generally speaking' this will amount to 'all human actions' (ta de prattomena panta), since virtually all our actions are within our power to do or not to do. ${ }^{36}$ The province of deliberation is more limited than this would suggest, however, because not all voluntary actions are deliberated about. ${ }^{37}$ Hence Aristotle affirms that we deliberate only about things concerning which we might take counsel. ${ }^{38}$ Our task is to consider which options are 'possible or impossible for us to perform, ${ }^{39}$ Deliberation consists in deciding 'whether we shall do this or that', ${ }^{40}$ and is as such identical to calculation (to logistikos). ${ }^{41}$

The key feature of this account is the term eph' hemmin, 'within our power' ${ }^{42}$ Aristotle is absolutely consistent that deliberation relates to things within the power of the deliberating agent to effect. ${ }^{43} \mathrm{He}$ puts this negatively as well as positively. We do not deliberate about eternal things such as the order of the universe or geometrical truths; nor wholly regular things such as solstices; nor irregular things such as the weather; nor random things such as finding treasure.$^{44}$ Or at least, he adds, if we $d o$ deliberate about such things, it simply shows ignorance of the causes involved. ${ }^{45}$ Everything caused by nature (physis), necessity (anagkē) and chance (tychē) is thus out, leaving only things caused by nous kai pan to di' anthrōpou, 'thought and everything produced by man' $;^{46}$ and even there, only things that can actually be changed by the deliberating agent himself (or itself in the case of collective agents) will be deliberated about. Other countries' political systems - Aristotle mentions those of Scythia and India - and how to spell given words will not be, since though these are undeniably human constructions, they are not within the relevant agent's power to alter. ${ }^{47}$

Deliberation thus presupposes that an agent faces a choice between at least two options, both of which must be possible for him or it to perform. An

35 NE 1112b8-12. Cf. NE 1140a35.

${ }^{36}$ Rhet. 1357a6-7, 25-30. Exceptions are those caused by chance (tychē), force (bia) and nature (physis): see e.g. Rhet. $1368 \mathrm{~b}$.

37 Rhet. 1359a35. Cf. EE 1248a30-b3.

38 Rhet. 1359a35.

39 Rhet. 1359b1-2; NE 1112b25.

${ }^{40} D A$ 434a8; EE 1226b11.

${ }^{41}$ DA 434a5-10; NE 1139a10-17. Cf. Sequic, Protagoras to Aristotle, p. 144. For a different view, see Olmsted, 'Ethical Deliberation', this volume.

42 More literally "“with," "for" or "from" ourselves'.

43 Unless, he allows, the deliberator is a fool or a madman, NE 1112a20-21. 'Within one's power' also includes using the agency of friends, NE 1112b27-29.

${ }^{44} N E$ 1112a21-29. Cf. EE 1226a28-33.

45 EE 1226a25.

46 NE 1112a30-32. Cf. Met. 1013a17.

${ }^{47}$ EE 1226a28-33; NE 1112a33-b3. 
assembly may approve a policy or reject it, a jury convict or acquit, a general pitch camp here or there, a doctor give this drug or none.$^{48}$ There is thus an intrinsic connection between deliberation and choice, as Aristotle makes clear. In both the Eudemian and the Nicomachean Ethics and again in the Rhetoric, his account of deliberation is wholly nested within his discussion of proairesis, 'choice'. ${ }^{49}$ The connection is also manifest at the level of definition. To proaireton, a thing chosen, is said to be equivalent to to probebouleuomenon, 'something previously deliberated', ${ }^{50}$ and to to bouleuton, an object of deliberation. ${ }^{51}$ Similarly, proairesis is defined as 'the deliberated appetite for things within our power' ${ }^{52}$ Deliberation and choice are not in fact coextensive: as Aristotle notes, while we deliberate about everything we choose, we do not choose everything we deliberate about. Many actions that we consider performing we end up deciding against. ${ }^{53}$ Still, on Aristotle's account, we do not deliberate about anything we cannot choose, nor can we choose something without having deliberated about it. To this extent, the scope of deliberation and choice is identical.

We may therefore restate the claim that we do not deliberate about ends in the language of choice. If we take Aristotle's argument at face value, it seems possible that we do not deliberate about ends because we do not choose them: they are beyond the scope of choice. Putting this together with the observation that deliberation concerns things within our power, we may infer that we do not choose ends because they are not within our power to effect. We are not their author: they owe their existence to some other cause, such as nature, necessity or chance. Could this be what Aristotle had in mind?

\section{III}

\section{The Meaning of Choice}

There is certainly sound textual support for the view that ends are not subject to deliberation because they are not chosen. Discussing choice in the Eudemian Ethics, Aristotle exactly echoed his claim about deliberation: no one chooses (proaireitai) any end, such as health or eudaimonia, but only things that conduce to an end (ta pros to telos). He continued: 'I mean for instance that no one chooses (proaireitai) to be healthy, but to take a walk or to sit down for the sake of being healthy; no one chooses to flourish, but to make

${ }^{48}$ EE 1227a18-19.

49 Also variously rendered 'decision', 'preference', 'purposive choice', 'rational choice', 'conscious choice' and 'deliberate choice'. See further Greek-English Lexicon, ed. H. Liddell, R. Scott and rev. H.S. Jones (Oxford, 1968), hereafter LSJ.

${ }^{50} N E$ 1112a16-17.

${ }^{51} \mathrm{NE} 1113 \mathrm{a} 3$.

52 That is, bouleutikè orexis tōn eph' hēmin, NE 1113a11-12. Cf EE 1226b17.

53 EE 1226 b17. 
money or to speculate for the sake of flourishing, ${ }^{54}$ Actually being healthy or flourishing would seem to be beyond our power; all we can do is perform actions that should, with luck, conduce to these goals. The point is repeated in the Nicomachean Ethics:

Wishing (boulēsis) is for the end, but choice (proairesis) is for things towards the end (tôn pros to telos). For instance, we wish to be healthy, and choose (proairoumetha) things through which we will become healthy, and we wish to flourish, and that's what we say, but it would not be appropriate to say that we choose to flourish, since speaking generally choice is concerned with things within our power (eph' hèmin). ${ }^{55}$

These passages strongly suggest that we are on the right lines. Yet the claim that ends are not chosen is also problematic. For one thing, it is prey to an even more challenging version of the criticism made of Aristotle's denial of deliberation about ends. A doctor may not deliberate about whether to heal, but it would seem to defy common sense to say that when he does heal, he does not choose to do so: he is, after all, free not to treat any particular patient, just as he was originally free not to become a doctor. For another, there is a major textual impediment. Many translations of Aristotle show him using the language of choice in conjunction with ends regularly. Rackham, for example, has him say that 'rightness in our choice of an end is secured by virtue', ${ }^{56}$ and that men have agency over their actions even if not over their 'choice of an end' ${ }^{57} \mathrm{Sim}$ ilarly, according to Ross, Crisp and Rackham, Aristotle's defence of eudaimonia as our ultimate end features the verb 'choose' not once but four times. 'For this we choose always for itself and never for the sake of something else, but honour, pleasure, and every virtue we choose indeed for themselves (for if nothing resulted from them we should still choose each of them), but we choose them also for the sake of eudaimonia .... 58

These objections may appear insuperable. But the textual problem, at least, is easily resolved. In none of these lines, nor any other, is proairesis actually paired with an end as its object. In the first, the item rendered 'choice of an end' is simply proairesis; the words 'of an end' are an interpolation by the translator. ${ }^{59}$ In the second, the term is telos, while 'choice of' is supplied. In the third, though there is a Greek referent for the word 'choose', it is not

${ }^{54}$ EE 1226a8-16. Cf. EE 1225b17-1226a8, 1227b37-40.

55 NE 1111b27-30.

${ }^{56}$ NE 1144a20, trans. H. Rackham (Cambridge, MA, 1944).

57 NE 1114b20.

${ }^{58}$ NE 1097b1-7, trans. Ross, rev. Urmson and Acrkrill. Cf. the translations of R. Crisp (Cambridge, 2000) and Rackham.

59 Rackham defends his approach on pp. 128-9 of his edition. 
proaireō but haireō, a different verb which may also be translated 'desire', 'pursue', 'take' or 'elect'. ${ }^{60}$

Haireo is in fact always the verb Aristotle uses when the coveted object is an end $;^{61}$ and though 'choose' has long been regarded as a fair rendering, it arguably ought to be abandoned, at least in translations of Aristotle. Translators normally distinguish between proaireō and haireō on the basis of rationality or purposiveness, noting the latter's association with animals and children as well as the former's with deliberation, yet Aristotle's own account points in a different direction. ${ }^{62}$ According to him, proairesis 'is' hairesis, 'not simply' but 'one thing before another' (heterou pro heterou). ${ }^{63}$ Similarly, something proaireton is pro heterōn haireton, 'chosen before other things' ${ }^{.6}{ }^{6}$ Evidently Aristotle took the hallmark of proairesis to be not so much rationality as the fact that more than one option was available. It meant choosing one thing rather than another. ${ }^{65}$ In contrast, hairesis neither suggested nor required the availability of more than one option, hence its alternative renderings 'desire', 'pursuit', 'taking', and even 'election', which makes sense in light of the fact that Greek elections were often not competitive. ${ }^{66}$ Yet in modern English a choice of only one option is held to be no choice at all. It follows that 'choose' ought to be avoided as a rendering of haireō, since it connotes precisely the kind of choosing between alternatives that Aristotle regarded as the distinctive feature of proairesis, in explicit contradistinction from the activity he says we engage in in relation to ends.

Far from taking ends to be the object of choice, then, Aristotle appears to have been scrupulous in observing the distinction between what we would call choice and a rather different form of pursuit. Yet there is another way that proairesis can be construed as relating to ends, and this takes us to the heart of

${ }^{60}$ LSJ. Cf. Tuozzo, 'Artistotelian Deliberation', p. 206, n. 20.

61 See e.g. EE 1294b17-21; NE 1097a25-35, 1103b30-35, 1113a18, 1112b1-5, 1138b15; Pol. 1323a20, 1323b19-20, 1333a28; Rhet. 1362a20, 1362b10. Note also the observation of Majithia that Aristotle never uses 'choice' (proairesis) in relation to contemplation, the only practical activity he says is undertaken strictly for its own sake (Majithia, 'Function, Intuition and Ends', p. 197).

${ }^{62} N E$ 1111a25, b5-10. See e.g. Crisp's defence of rendering proairesis 'rational choice', Bryn Mawr Classical Review, 18 October 2001.

${ }^{63}$ EE $1226 \mathrm{~b} 8$.

64 NE $1112 \mathrm{a} 16$.

${ }^{65}$ LSJ. This, of course, explains its connection to deliberation: in any self-generated action, an agent necessarily faces a minimum of two options, to do $x$ or not to do $x$.

66 E.S. Staveley, Greek and Roman Voting and Elections (Ithaca NY, 1972), pp. 87-8; M.H. Hansen, The Athenian Democracy in the Age of Demosthenes (Norman OK, 1999), pp. 233-5. 
the modern account of this issue. ${ }^{67}$ This is the suggestion made by Ross in 1923 that 'outside the two passages in which proairesis is formally discussed ... it generally means "purpose" and refers not to means but to an end ${ }^{68}$ Here, if I understand correctly, the claim is not that proairesis is used with an end as its object, but that in being used to mean 'purpose', proairesis itself meant something close to 'end'. Certainly Ross's citations point in this direction: the most common such usages he finds are references to previously adopted plans, such as 'if this enquiry belongs to political science, clearly the pursuit of it will be in accordance with our original plan' (proairesin) ${ }^{69}$ And in every case he mentions, it is true that proairesis can be rendered 'purpose' — or 'plan', 'programme', 'intention' or 'aim' — and thus made synonymous with 'end'. Is there any way to draw the sting from this argument?

One possibility is suggested by Sorabji. Concerned that Ross's claim 'weakens the link between proairesis and rationality', since if ends can be chosen it is 'no longer clear that one chooses something for a reason - that it conduces to something else', Sorabji emphasized that many ends are actually means in longer chains of deliberation and action. ${ }^{70}$ Outside the Nicomachean Ethics, he supposed, proairesis may have lost its link to means and thence to rationality, but he denied that Ross's citations from that text required that interpretation. Rather, in every case, the relevant end pertained to some further end, and was therefore really a means. We thus needed 'only to remember that we can choose ends, so long as they are related to further ends', and so long as that relationship was relatively broadly conceived, extending to instance, manner and part as well as properly instrumental means. ${ }^{71}$

It is perfectly true that in Aristotle's view, most ends are not final but pertain to some further end, and so can equally plausibly be regarded as means. As Aristotle says himself, only eudaimonia is never desired (hairoumetha) for the sake of something else; even its constituents are desired both for their own sakes and for that of eudaimonia. ${ }^{72}$ Yet there is more to say about Sorabji's argument and the claim of Ross that motivated it. If we can choose ends only so long as they are related to further ends, it follows that eudaimonia itself cannot be chosen. This would not necessarily be a problem, but for Sorabji it

${ }^{67}$ Nussbaum implies another: she identifies proairesis as 'deliberation concerning [one's] ultimate ends or values' (Nussbaum, Fragility, p. 284). I cannot find any textual support for this reading.

68 W.D. Ross, Aristotle (London, 1923; 6th edn. 1995), pp. 207-8.

${ }^{69}$ NE 1102a13 trans. Ross, rev. Ackrill and Urmson. See also Pol. 1301a19, 1324a21; NE 1136b15, 1179b35. For the full list of citations see Ross, Aristotle, p. 240.

${ }^{70}$ Sorabji, 'Role of Intellect', p. 110. See e.g. NE 1094a1.

71 Sorabji, 'Role of Intellect', pp. 110-11. Kolnai's final position is similar: his 'ends' are equivalent to Sorabji's ends that pertain to further ends, or means, and his 'themes' or 'interests' to Sorabji's further ends. See Kolnai, 'Deliberation is of Ends', p. 202.

${ }^{72}$ NE 1097b1-7. See also NE 1094a15, 1112b12-20 and 1176b28-35. 
is, because he depends on the 'further ends' argument to secure the link between choice and rationality. Eudaimonia has no further end; is our pursuit of it then irrational? Sorabji does not say, but unhappily, if the answer is yes, then so is our pursuit of every lesser end pertaining to it, and if no, the link between choice and rationality does not hold. Either way, the argument self-destructs. Some other way of neutralizing Ross's claim must be found.

Ross himself provides a clue as to how this might be done. It is true that proairesis can often be rendered 'purpose'. Yet it is also true, though Ross did not note it, that in every such case it can also be rendered 'choice' with no loss of sense. What exactly is going on here? The answer lies in the ambiguity of the word 'choice', which can refer either to the act of choice-making (proairesis) or to the thing chosen (proairesis or to proaireton) $;^{73}$ and this has significant consequences for our conceptualization of ends. From the perspective of the act of choice-making, it seems natural to conceive of all options before an agent as means to a given end. Yet once one of those options has been chosen, it seems equally natural to conceive of that option as the agent's new end, allowing the original end to recede into the background. The term 'choice' may thus be regarded in the light of either means or end, but the ends in each case are not the same. To avoid confusion we need to specify exactly what each end is the end of. Are we discussing the end of the agent's most recent chain of reasoning - to proaireton, the action about to be performed - or the end of that action, the original telos? If the original telos, what is its end? Is it some other action, or something more distant than that?

Asking what each end is the end of draws attention to a significant fact. Aristotle seldom attributed ends directly to agents. Rather, most things he identified as ends were ascribed to actions, practices and chains of reasoning. In relation to the relevant agents, such ends — as Sorabji spotted — only had the status of means; and much difficulty arises if these relations are confused.

\section{IV \\ Ends and Agents}

Let us establish some of the things Aristotle called ends. The supreme end of human life he declared without hesitation to be eudaimonia, 'flourishing, ${ }^{74}$ also designated to eu zên, 'living well', ${ }^{75}$ to eu prattein, 'doing' or 'faring well', ${ }^{76}$ and eupraxia, 'doing well' ${ }^{77}$ Its constituents, such as health, ${ }^{78}$ hon-

73 LSJ.

${ }^{74}$ EE 1217a20; Met. 994a10; NE 1095a15, 1097b1, 1176b1 ff.; Rhet. 1360b5.

75 NE 1095a15, 1140a25; Pol. 1252b30, 1278b20, 1281a1. Cf. Oec. 1343 a10.

76 NE 1095a15.

77 NE 1139a5, 1140b3; Pol. 1325b15.

${ }^{78}$ EE 1214b15, 1216b18, 1217a35, 1218b19, 1227b26, 28-33; Met. 1013a24, 1032b10, 20; NE 1094a8, 1097a20; Pol. $1257 \mathrm{~b} 25$. 
our, ${ }^{79}$ good reputation, ${ }^{80}$ wealth,${ }^{81}$ culture,${ }^{82}$ knowledge and contemplation,,${ }^{83}$ pleasure ${ }^{84}$ friendship ${ }^{85}$ and virtue,${ }^{86}$ were also ends. ${ }^{87}$ So too were the aims of practical arts and sciences such as healing, convincing, and producing law and order, ${ }^{88}$ achieving military victory ${ }^{89}$ and making ships, houses and flutes. ${ }^{90}$ Actions, such as taking a walk, having a drink or making a cloak, were also ends, ${ }^{91}$ as were more abstract goals such as the just and the advantageous,${ }^{92}$ faculties such as phronesis, logos and nous, ${ }^{93}$ and mental productions such as speculative propositions, the truth, and statements of what one ought or ought not to do. ${ }^{94}$

Encountering this long and varied list for the first time, one might well be tempted to throw up one's hands and declare that, after all, ruling out deliberation about ends would be utter folly. Clearly, Aristotle recognized dozens of ends, and he could hardly have meant to deny that we can deliberate about, say, whether to go for a walk or not: that would seem absurd. It would seem equally absurd to deny that we deliberate about various other ends scholars have proposed, such as buying dresses,${ }^{95}$ holidaying, ${ }^{96}$ running two miles five

${ }^{79}$ EE 1214b8, 1248b28; NE 1095b15, $1097 \mathrm{~b} 3$.

80 EE 1214b8; Pol. 1323a35.

${ }^{81}$ EE 1214b8, 1217a35, 1248b28, 1249b18; NE 1094a10, 1096a6, 1097a25; Pol. 1258a10, 1323a25; Rhet. 1366a4.

82 EE 1214b8; Rhet. 1366a5.

83 EE 1216b14; NE 1177a15.

${ }^{84}$ EE 1218b30; NE 1095b15, 1097b3, 1174a20.

85 EE 1249b18.

${ }^{86}$ EE 1218b30; NE 1095b17; Pol. $1323 \mathrm{a} 25$.

87 See similarly physical fitness, EE 1227b27-28, 1248b28, 1249b18; amusement, NE 1176b10; power, Pol. 1323a35; peace, Pol. 1334a12; leisure, Pol. 1334a12, 1337b35; performing noble actions, Pol. 1281a7; and living in a polis, Pol. $1252 \mathrm{~b} 30$.

88 NE $1112 \mathrm{~b} 12$.

89 NE 1097a20.

90 NE 1094a9, 1097a20-25.

91 MA 701a12-33. Cf. Met. 1050a15.

92 Rhet. 1358b20-30, 1362a20.

93 EE 1218b30; Pol. 1334b5.

94 MA 701a10; Met. 993b20; NE 1143a9-10.

95 Kolnai, 'Deliberation is of Ends', p. 199. He also discusses buying an encyclopaedia, pack of cigarettes or holiday; visiting a friend, saving money, relieving a headache, protecting one's stomach, winning a prize, and getting in at the next election (ibid., pp. 199-202).

96 Majithia, 'Function, Intuition and Ends', p. 189. He also discusses having children, stamp collecting, pursuing careers in music, law, politics, skateboarding or surfing, saving one's beleaguered comrade, playing golf, getting a haircut and investing in military or cultural activity (ibid., pp. 189-97). 
times a week except in heavy rain, ${ }^{97}$ balancing all one's life goals, ${ }^{98}$ having an amusing evening, ${ }^{99}$ even deliberating itself. ${ }^{100}$

Yet just because Aristotle would have agreed that all these objects can be regarded as ends, and that almost all can be deliberated about, it does not follow that he would have subscribed to the view that agents deliberate about their ends. We must ask what each end is the end of, and the results are illuminating. Scholars invariably conceive of ends as the ends of agents, as indicated by their liberal use of possessive adjectives in this context. A doctor perceives healing as good 'and indeed all her other ends as well'; ${ }^{101}$ running two miles five times a week is 'my specification of one component of health', and so on. ${ }^{102}$

But Aristotle did not think like this. To be sure, possessives are ordinarily rare in Greek: thus Aristotle does not say that nobody deliberates about 'his' end, but 'the' or 'an' end (tou telous) ${ }^{103}$ Yet he does normally specify what given ends are the ends of, and that subject is almost never a personal agent. The opening lines of the Nicomachean Ethics indicate his approach. The ends mentioned there are those of actions (praxeōn), arts (technōn) and sciences (epistēmōn), not of agents. ${ }^{104}$ Actions, in fact, are the most common possessors: health is the end of walking, work of play, and peace of war. ${ }^{105}$ Practical arts are also common: thus healing is the end of medicine, convincing of rhetoric, wealth of estate management, and so on. ${ }^{106}$ Other possible subjects include theoretical sciences, ${ }^{107}$ choices, ${ }^{108}$ modes of life, ${ }^{109}$ nature, ${ }^{110}$

97 Nussbaum, De Motu, p. 208.

98 Ruderman, 'Recovery of Political Judgment', p. 415.

99 Wiggins, 'Deliberation and Practical Reason', pp. 32, 38. He puts having a satisfying profession and an interesting holiday in the same category (ibid., p. 38).

100 Bickford, 'Beyond Friendship', pp. 415-18.

101 Majithia, 'Function, Intuition and Ends', p. 189.

102 Nussbaum, De Motu, p. 208.

103 NE 1112b12-16.

$104 N E$ 1094a1-10.

105 EE 1227b27-28; Met.994a15, 1013a24; Pol.1337b35, 1176b10-13; NE 1094a1, 1177b5-10; Pol. 1325a1. For similar examples, see EE 1227b27-28; Met. 996a25, 999b20, 1022a10; NE 1097a23-25, 1110a12, 1140b15, 1176b35; Pol. $1339 b 30$.

${ }_{106}$ EE 1216b18-19, 1218b14; NE 1094a10; Pol. 1257b25; Rhet. 1355b, 1358b, 1391b, 1393a. For similar examples, see $N E$ 1094a1, 1095a15, 1139a5, 1140b6, 1177b5-10; Pol. $1257 \mathrm{~b} 25$.

107 EE 1216b12. Cf. Met. 993b20, $1064 b 15$.

108 NE 1094a1, 1097a23.

109 NE 1095b15-1096a10.

110 DA 415b15, 434a26; Met. 1050a18, 1065a25. 
political systems, ${ }^{111}$ parts of the mind, ${ }^{112}$ 'everything which is generated', ${ }^{113}$ and the constituents of eudaimonia. ${ }^{114}$

By contrast, there are only two agents in this category. These are human beings both severally (tōn anthrōpinōn) ${ }^{115}$ and collectively (in the form of the polis), ${ }^{116}$ and practitioners of arts such as the doctor, orator, statesmen, athletic trainer and teacher. ${ }^{117}$ Still more important, the ends ascribed to these agents are exceedingly few. The only ends ascribed directly to human beings are eudaimonia and its constituents, ${ }^{118}$ while those of practitioners of arts are only those of their respective arts. ${ }^{119}$ Every other end Aristotle mentions is described not as the end of the relevant agent but as something conducing to one of their ends, i.e. as a means from the agent's point of view.

The concept 'telos of an agent' thus seems to be reserved for something quite distinct. In the cases of both human beings and practitioners of arts, Aristotle applies it only to their ultimate ends, those for the sake of which everything pertaining to their role is done. We may ask why he did not use this locution more freely, to refer to objects such as buying dresses, going running, or enjoying amusing evenings, and the best answer seems to be that such actions cannot be construed as the end of these agents' life-activity as a whole. A telos, according to Aristotle, belongs to a complete thing. ${ }^{120}$ This is why the term so often appears with actions: any action, once accomplished, is complete. ${ }^{121}$ But a human life is not complete until death. ${ }^{122}$ Hence an agent's telos, properly speaking, will be the object of all his actions until death, or in the case of practitioners of arts, until they cease to practice their art. Buying dresses, going running, and having amusing evenings scarcely figure in these contexts.

Seen in this light, the task of making sense of Aristotle's denial of deliberation about ends seems suddenly much easier. Rather than explain why no end can be deliberated about, we need only establish why eudaimonia and the ends of practitioners of arts cannot be. To restate our question in the language of choice, we may ask: Why might Aristotle have thought that eudaimonia and the ends of arts were beyond an agent's power to choose? The answer falls

111 Rhet. 1366a5-10.

112 DA 415b15, 433a10-15; Met. 1065a25; NE 1143a10.

113 Met. 1050a8.

114 Met. 994a15; NE 1097a25; Pol. 1256b25-40.

115 NE 1176a33. Cf. HA 500b25-32, 501a1.

116 Pol. 1252b30; Rhet. 1360b5-1362a. Cf. Oec. 1343a10.

117 NE 1112b12; EE 1227b27-28; Met 1050a18.

118 EE 1226a10-18, 1227a14; NE 1097b3, 1147b25, 1168b, 1176a30; Pol. 1252b30, 1338a5; Rhet. 1360b5-1362a.

119 NE 1112b12; EE 1227b27-28; Met. 1050a18.

120 Met. 1023a30; Pol. 1339a30.

121 MA 700b13, 30; Met. 999b10, $1048 b 19$.

122 NE 1100a5-1101a22, 1176b1. Cf. EE 1219b1-8; Met. 1048b19-38. 
under three headings, nature, language and politics — with the single caveat that on Aristotle's view of human beings, the latter two categories must be regarded as elaborations of the first. Uniting all three categories, moreover, is a single theme: the nature of human beings as collective animals.

\section{V \\ The Origins of Ends}

In the Nicomachean Ethics, as we saw, Aristotle identified four or five distinct causes of existence: nature, necessity, chance and 'thought and everything produced by man'. ${ }^{123}$ The Rhetoric presents a similar breakdown of the causes of human action. 'All the things people do' are said to be caused either by the agents themselves (di' hautous) or by something else (ou di' hautous). Acts caused by agents are generated either by habit (èthos) or by appetite (orexis), and if by appetite, either rationally via calculation (logismos) or non-rationally via anger (orgē, thymos) or desire (epithumia). Acts caused by something else are generated either by chance (tychē) or by necessity (anagkē), and if by necessity, either by force (bia) or by nature (physis). ${ }^{124}$

I suggest that Aristotle put the pursuit of ends in the final category. Human beings do not pursue eudaimonia, nor doctors healing, because at some prior point each agent chose to do so, but because it is part of their nature. The fact that eudaimonia is the end of human beings and healing of doctors is not in anyone's power to change. Or at least, echoing Aristotle, we may say that if anyone did try to change such things, it would simply show ignorance of the causes involved. ${ }^{125}$

It is relatively easy to see that Aristotle took the pursuit of eudaimonia to be given by nature. We cannot help but pursue things that seem good to us, and the constituents of eudaimonia seem good to us by nature. ${ }^{126}$ Though the absolute standard of good is the good man, ${ }^{127}$ Aristotle does not suggest that bad men will fail to perceive the various constituents of eudaimonia as good. Bad men do not go wrong because they choose bad ends, that is to say. ${ }^{128}$ Rather, they go wrong initially because they choose bad means to ends that everyone regards as good. Where virtuous choices are available, they seek more pleasant

123 NE 1112a30-32. Cf. Met. 1013a17.

124 Rhet. $1369 \mathrm{a}-\mathrm{b}$.

125 EE 1226a25. See above, Section II, paragraph 3.

${ }^{126}$ EE 1217a20, 1218b19-25, 1227a18-39, 1248b27-34, 1294b17; Met. 980a22; NE 1095a15-20, 1113a15-1114b, 1173a1; Pol. 1278b25, 1323a35, 1323b; Rhet. 1360b. Whether everything that seems good to us really is good for us is a different question. It depends on how our characters have developed up to that point (see e.g. EE 1248b27-34).

127 NE 1113a29-36, 1176a17-22.

128 Here I part company with Wiggins, 'Deliberation and Practical Reason', p. 31. See EE 1228a2-5; Rhet. 1366a15, 1417a. 
shortcuts, until they are scarcely capable of virtuous action. ${ }^{129}$ They go wrong next because they do not perceive correctly which goods are limited. Wealth, honour and pleasure are limited; one can have too much of them, unlike health or virtue. ${ }^{130}$ Yet in pursuing wealth, say, as though it were limitlessly good, ${ }^{131}$ the bad man does not thereby make wealth his ultimate end. He does not have that power. Rather, he misapprehends his end, particularly the role of virtue within rather than simply as a means to it. ${ }^{132}$ This is not a failure of deliberation, ${ }^{133}$ but of virtue, because vice clouds nous, the part of reason that Aristotle held to be responsible for apprehending things as they are. ${ }^{134}$ The nature of human flourishing, for him as for the rest of the species, remains unchanged. ${ }^{135}$

Those scholars are thus mistaken who hold deliberation and phronessis alone to be responsible for identifying things as good. They do have that role in relation to means, but not to agents' ends. ${ }^{136}$ Equally, it is a mistake to think that the constituents of eudaimonia can be deliberated about. Nussbaum, for example, suggests that Aristotle believed that 'we can always ask of some putative constituent, e.g. friendship, whether or not it really belongs there as a constituent of the end, that is, whether life would be less rich and complete without it' ${ }^{137}$ But Aristotle did not think that it is up to us to decide whether life would be less rich and complete without friendship. It simply would be. This does not mean that certain elements of eudaimonia may not be found more desirable than others, or that one may not be prioritized over another in a given situation; Aristotle had no issue with ranking goods in this way. ${ }^{138}$ But that the constituents of eudaimonia are our ends is not open to deliberation. This is why Aristotle talks of 'searching for', 'establishing', 'defining' and 'knowing' eudaimonia, rather than 'choosing' or 'deciding' it. ${ }^{139}$ It is also why

129 NE 1113b5, 1152a15-25, 1162b35; Rhet. 1370a, 1372b. Cf. E. Garver, Confronting Aristotle's Ethics: Ancient and Modern Morality (Chicago and London, 2006), pp. 41-3. This process takes a long time. Children possess natural virtue; it is quite hard to become thoroughly bad. NE 1137a5-20, 1144b5.

130 Pol. $1257 \mathrm{~b} 25$.

131 See Pol. 1256b25-1257b35.

132 Pol. 1258a12, 1323a35, 1333b1.

133 Except indirectly, insofar as the bad man's misapprehension is the result of the character-altering effects of his previous choices. See note 129 above.

${ }^{134} D A$ 433a25; EE 1227b21-28; MA 701a30-35; NE 1140b15, 1141a7, 1145a2, $1176 \mathrm{a} 15$.

135 NE 1094b1-10; Pol. 1278b25, 1324a1; Rhet. 1360b5-1362b15.

136 Allan, 'Aristotle's Account', p. 75. Cf. Annas, 'Virtue Ethics', p. 528; Irwin, 'Aristotle on Reason', p. 578; Olmsted, 'Ethical Deliberation', this volume.

137 Nussbaum, Love's Knowledge, p. 62. Cf. Nussbaum, Fragility, p. 297.

138 Rhet. 1363b-1365b20.

139 EE 1214b5, 1218b10; Met. 982b5, 995a23; NE 1094a25, 1095a15, 1097a15-29, 1112b20; Pol. 1323a15, 1332a5. See further Michael Woods, 'Intuition and Perception 
he describes the political philosopher, rather than, say, the ruling body in the polis, as the 'master-craftsman' of the end. ${ }^{140}$ This is not just selfaggrandizement. If our ultimate end is given by nature, establishing it is necessarily a theoretical rather than a practical task, requiring not deliberation and phronēsis but philosophy and nous.

That Aristotle took eudaimonia and its constituents to be given by nature thus looks plausible. That the ends of practitioners of arts are natural does not. As has been suggested, doctors must choose to become doctors; they thus choose to make healing (or 'treating well', as Aristotle put it in the Rhetoric) their end. ${ }^{141}$ How then can we say that practitioners of arts pursue their ends by nature?

We may first observe that Aristotle does, in fact, use the language of nature to describe the doctor's end. Though a builder may restore someone to health by accident, 'it is not a builder but a doctor who naturally (kata physis) does this' ${ }^{142}$ Thus encouraged, we may consider what happens when agents practice arts, and why they do so. The doctor's end, certainly, is healing. Yet what is the agent's end in becoming a doctor? Not healing but eudaimonia. Indeed, a medical career may seem particularly rewarding in this respect, since it can potentially conduce towards several constituents of eudaimonia at once: knowledge, honour, wealth and so on. ${ }^{143}$ What then is the relationship between healing and eudaimonia from the agent's point of view? The claim that the doctor 'makes healing his end' suggests that they are equivalent, but this is not the case. Anyone who proclaimed 'healing' to be his end would be thought a monomaniac. (Anyone who took it to be healing some particular patient would be thought crazier still.) In choosing medicine as a means to eudaimonia, the agent does not in fact choose 'healing' as a further end; he chooses it inasmuch as he chooses medicine. 'Medicine' and 'healing' are from his perspective simply two descriptions of the same thing.

The mistake scholars have made, then, is to conflate the end of medicine with the agent's end in becoming a doctor. This is unfortunate, because it leads to the mistaken inference that the reason that doctors do not deliberate about their end is that they had already decided that they would become doctors. ${ }^{144}$ But the fact that doctors heal does not depend on the prior choice of any given agent to become a doctor. Healing is part of the nature of doctoring. As such it is not up for deliberation, by would-be doctors or by anyone else.

in Aristotle's Ethics', Oxford Studies in Ancient Philosophy, 4 (1986), pp. 145-66; Segric, Protagorus to Aristotle, pp. 155-7.

140 NE 1152b1-4.

141 Rhet. $1355 \mathrm{~b} 12$.

142 Met. $1027 \mathrm{a} 1$.

143 Rhet. 1365b5-10.

144 As in e.g. Nussbaum, De Motu, p. 171. 
This leads to a crucial point. 'Doctors heal' is both an observation about the nature of doctoring and a partial definition of the term 'doctor'. ${ }^{145}$ For human beings, these features are closely connected, because we are linguistic animals - that is, we have logos - by nature. ${ }^{146}$ But they are not quite the same thing, and it is at the level of language that most criticisms of Aristotle's denial of deliberation about ends have taken hold. Wiggins, for example, argues:

In any non-technical deliberation, I should characteristically have an extremely vague description of something I want - a good life, a satisfying profession, an interesting holiday, an amusing evening — and the problem is not to see what will be causally efficacious in bringing this about, but to see what really qualifies as an adequate and practically realisable specification of what would satisfy this want. Deliberation ... is not primarily a search for means. It is a search for the best specification. Till the specification is available there is no room for means. ${ }^{147}$

If I understand correctly, Wiggins means that before we can consider what to do in order to have, say, an amusing evening, we must first define our terms. This is why he believes that all ends not only can but must be deliberated about; the agent must arrive at a view of what his end means. Do I define 'an amusing evening' as a trip down the pub with friends, a game of pool, or a night watching TV? Until I have decided, I cannot begin to think how to go about actualizing the end. Nussbaum, embracing this logic, posits 'running two miles five times a week except in heavy rain' as 'my specification of one component of health' ${ }^{148}$ Running two miles five times a week is 'what is to count as' exercise for her, the necessary precursor to the purely instrumental acts of putting on running clothes and heading out of the front door. ${ }^{149}$

Deliberation, on this account, is primarily a problem of definition. Yet it is not clear that the meanings of words are open to being decided in the way that Wiggins and Nussbaum suggest. Language is a collective enterprise: terms have meaning for the entire linguistic community, not for each member individually. ${ }^{150}$ Someone who said that, as a doctor, his end was to advise clients on their tax returns would not be thought crazy in the same way as someone who said his end was to heal some particular patient, but it would be assumed that he did not understand what the word 'doctor' meant. Similarly, there is no

145 Cf. A.W. Price, 'Aristotle's Ethics', Journal of Medical Ethics, 11 (1985), pp. $150-2$, p. 150. Having stated that no one deliberates whether to be happy, just as no doctor deliberates whether to heal, he goes on: 'But the point is formal, almost verbal: just as I'm not 'doctoring' unless I am trying to make a patient well, so I'm not deliberating unless I'm trying to live well' (italics mine).

\footnotetext{
146 EE $1224 \mathrm{~b} 30$.

147 Wiggins, 'Deliberation and Practical Reason', p. 38.

148 Nussbaum, De Motu, p. 208.

149 Cf. Nussbaum, Fragility, p. 287.

150 Wittgenstein, Philosophical Investigations, esp. §§258-77.
} 
such thing as what counts as 'exercise' or 'an amusing evening' for me. Nussbaum's claim that 'running two miles five times a week' is her specification of one component of health is thus misleading. What she presents is not, in fact, a definition of the term 'exercise', but rather a description of her chosen means towards that end. Similarly, a trip to the pub, a game of pool, and a night watching TV are three possible means to the end 'an amusing evening'. To the extent that we do not find the prospect of these activities appealing, we simply decide against them. But we do not need a more precise definition of 'amusing evening' in order to do that. We may, of course, offer one anyway, just as we may debate what we mean by 'the good life', 'an interesting holiday', and so on. But if we do, we will be engaging in philosophy rather than in practical reasoning. ${ }^{151}$

This, finally, brings us to politics. For the fact that our ends are given by nature, and that meanings are beyond the power of individuals to decide, does not mean that we cannot change either the natures of practices or the meanings of words. ${ }^{152}$ It just means that we have to do it collectively. Here, we may turn to Bickford's discussion of the doctor's end. Even if 'healing' or 'treating well' is deemed an acceptable general account, she argues, this still leaves much to be decided. Is the exact purpose of doctors 'to prolong life at any cost? to spare pain? to allocate society's resources in a particular way? simply to make clear the various options and consequences, and let the patient decide? ${ }^{153}$

To the extent that this question refers to the treatment of any particular patient, these options - as in the case of the amusing evening — are not to be regarded as alternative specifications of the doctor's end, but as competing means to that end, of which 'treating well' is arguably an adequate rendering. To the extent that they represent competing general accounts of the doctor's end, however, they are open to deliberation and thence to change, though not at the hands of individual agents. They are questions for entire communities to consider. Either consciously through legislation and policy-making, or less consciously through the development of language and convention, issues such as the acceptability of prolonging life at any cost or the most desirable allocation of resources are decided not by individuals (unless the community grants it), but by socially developed norms and laws, in the same way that all arts and practices are developed and patrolled.

151 Cf. Annas, 'Virtue Ethics', p. 521.

152 We cannot, on Aristotle's account, change the constituents of eudaimonia. But this is not the problem it may at first appear, because most if not all of them are very general. To be sure, how we might go about achieving honour today, say, differs from what Aristotle might have had in mind; but being honoured is still regarded as something to aim for.

153 Bickford, 'Beyond Friendship', p. 402. 
To the extent that an issue is uncontroversial, legislation will probably prove unnecessary. That doctors are to heal falls into this category. Other questions are more fraught. Are assisted suicide or abortion part of what it means to 'treat well'? Does cosmetic surgery count as medicine? To return to a question raised earlier, may a doctor deny someone care who asks for it? In what circumstances? These are not philosophical but practical questions, though the agent in relation to whom they are practical is not single but collective - either the whole community or some dependent body empowered to decide on its behalf; and once that agent makes its decision, a limit is placed on the individual's capacity to choose otherwise. 'As for example on the occasion of some strange and deformed birth, it shall not be decided by Aristotle, or the philosophers, whether the same be a man or no, but by the laws. ${ }^{154}$ The words are Hobbes's, but I do not think that Aristotle would have disagreed.

The limits on individual deliberation are thus threefold. Across the species, limits are given by nature; across the linguistic community, by language; and across the political community, by law. It is entirely in line with Aristotle's philosophy that we should be limited in these ways, because we are, according to him, by nature rational (hence linguistic) and political (hence collective) animals. We are political animals because we share a common task, or ergon, which is to flourish both collectively and severally, and for this we need each other's help. ${ }^{155}$ What makes us more political than any other animals, moreover, is our possession of logos, which enables us to argue among ourselves about what we take to be just and advantageous for our communities and ourselves. ${ }^{156}$ Not only our activities, then, but also how we interpret them are fundamentally and by nature a joint enterprise; and, according to Aristotle, the work of each thing is its telos. ${ }^{157}$

\section{VI \\ Conclusion}

Aristotle's denial of deliberation about ends has been widely contested, spurred by the fear that if we do not choose our ends though reason, our pursuit of them must be irrational. This article has shown that that fear is misplaced. Far from thinking that we choose our ends irrationally, Aristotle denied that we choose our ends at all. Agents' ends are given by nature, which in the case of human beings includes roles for language and politics. Deliberation, however, on Aristotle's conception, concerns only what is within the power of the deliberating agent to effect. Ends are thus beyond the scope of

154 Hobbes, Elements of Law, 29.8.

155 See EE 1219a9, 1219b1-8; HA 488a8; Met. 1050a20. See also Yack, in this issue, and D. Cammack, 'Aristotle on the Virtue of the Multitude', Political Theory, 41 (2013), pp. 171-202, p. 193.

156 Pol. 1253 a15.

157 EE 1219a9. 
deliberation, although not beyond reason, for they are apprehended by nous, the part of logos involved in perceiving ends and philosophizing about them, should we care to do so.

Seen in this light, the best translation of telos may in many cases be 'point', rather than the more promiscuously used 'end'. ${ }^{158}$ The point of deliberating is to act; the point of acting is to flourish. It is not the point of anyone's life to buy a dress, go running, or have an amusing evening. Those aims are indeed the point of the actions that lead up to them, but it would seem odd to say that they were the 'point' of the agent who performed them. That the point of life is to flourish, however, or the point of doctoring to heal, does not sound quite so implausible, even to non-Aristotelian ears. Nor, I think, does it seem absurd to suggest that such 'points' are not open to individual choice, but are given in the nature of the activities involved.

We ought to find this picture attractive, for two reasons. First because achieving our ends would otherwise be impossible. We do not need to agree on ultimate values or ideal institutions in order to live collectively: ${ }^{159}$ to borrow a slightly dated example from Kolnai, conservative liberals, radical democrats, communist totalitarians and fascist totalitarians can continue to argue about 'the conception of a good constitution'. ${ }^{160}$ But without a shared language, which is to say substantially overlapping agreement on the referents of terms, if not on their exact specifications, even such arguments would be impossible. ${ }^{161}$ We depend on common experiences to make ourselves understood to each other, and thence to gain what we need from each other in order to flourish both collectively and as individuals. Though the means we individually choose to realize our ends may be unique, our capacity to realize those ends rests at least in part on the fact that they are shared.

The second reason that this picture should seem attractive, at least to those who have worried that the denial of deliberation about ends constitutes an embrace of Humean irrationalism, is that the claim that human beings can act rationally is predicated on it. As we have seen, according to Aristotle, logos is twofold, both practical and theoretical; so our possession of theoretical reason, including nous, would sufficiently justify his claim that human beings are rational animals. Yet in order to act we need something more than the power of contemplation supplied by the theoretical intellect - we need phronēsis, practical wisdom or prudence, the part of the intellect that Aristotle associates with deliberation; and in order for deliberation - and thence the actions that it generates - to be rational, it must, at some point, come up against

158 Cf. Majithia, 'On the Eudemian and Nicomachean Conceptions of Eudaimonia', p. 317; Segric, Protagoras to Aristotle, p. 111.

159 Cf. Mulgan, 'Ethical Diversity', esp. pp. 191-2.

160 Kolnai, 'Deliberation is of Ends', p. 197.

161 Cf. Wittgenstein: 'If a lion could talk, we could not understand him.' Philosophical Investigations, trans. G.E.M. Anscombe (Malden MA, 2001), p. 190e. 
something that is not self-generated. As Aristotle argued, there must be a 'stop': the alternative is to abolish the very nature of the good and with it the possibility of intelligent action. ${ }^{162}$ This is because instrumental reason rests ultimately on necessity, and there is no necessity to voluntarily chosen human action. ${ }^{163}$ This is what makes us free: yet if we never, in the course of our deliberations, run across something beyond our power to change, the paradoxical result is that there will be no point to any of our actions. Everything we do and become could have been otherwise, and the only reason that it is not, it seems, will be that we did not wish it so; and if we ask why we did not wish it so, the only available answer will be that we did not desire it. Practical reason, on this picture, becomes irrelevant.

Sorabji was thus right to say that if we choose our own ends, it is 'no longer clear that one chooses something for a reason - that it conduces to something else', and that this dissolves the connection between choice and rationality. ${ }^{164}$ His solution to this problem - to say that we can choose ends so long as they are related to further ends, i.e. so long as they are really means - did not, as we have seen, quite suffice, because it left open the question of how our pursuit of eudaimonia can be unchosen and yet not irrational. But his basic point was sound. The rational quality of practical reason depends on the existence of a 'something else' that is not itself up for grabs, or we end up chasing our own tails. Absent some final external necessity, captured by Aristotle in the term telos, our actions could only be the result of mere whim, and that is a more Humean picture than anything Aristotle suggests.

There is thus a deep irony in the attempt to save Aristotle from the ostensibly Humean consequences of his denial that we deliberate about ends. Far from saving Aristotle from Hume, his rescuers end up having to be saved from Hume themselves.

Daniela Cammack

HARVARD SOCIETY OF FELLOWS

162 Met. 994a7-10, 994b9-17; NE 1113a1-2, 1142a30; EE 1248a17-22.

163 EE 1223a1-20; NE 1109b30-1110a12.

164 Sorabji, 'Role of Intellect', pp. 110-11. 